\title{
日本列島及び周辺の地震活動 一海溝付近の巨大地震と内陸地震一
}

SEISMIC ACTIVITY IN AND AROUND JAPAN ISLAND ARC

- LARGE EARTHQUAKE NEAR TRENCH AND INLAND EARTHQUAKE -

\author{
西田良平 \\ 鳥取大学工学部土木工学科
}

\begin{abstract}
地震は古来災害で一番恐れられ、古文書にも数多くの記載がなされている。我国において、地震の記載が 最初にあるのは、日本書紀(養老 4 年 (720) ) 允恭天皇記の 5 年 7 月 14 日 $(416 \cdot 8 \cdot 13$ ) の河内地震である。それ 以後、記録されている被害地震は 400 を越えている。地震はその原因が判らず、「地下の大なまず」の仕業に され、神業・祈祷・陰陽道などで天変地異として理解していた。しかし、最近、プレートテクトニクス説で 説明される地球科学の理論で、地球内部での現象、地震のメカニズム、火山活動などが明らかにされている。

2000 年春から、北海道有珠山の噴火、伊豆諸島の三宅島・神津島の地震活動と噴火、そして鳥取県西部地 震を始めとする日本海沿岸地域に多発する地震と、最近活発な時期に入ったと見ることができる。山陰地方 では、過去の大地震の発生、微小地震の帯状配列と、日本海沿岸に沿った地震活動がこの地域の特徵である。 火山分布・地形分布などとの対比もこの形状と同じであり、地下のいろいろな構造がこの傾向を示している。
\end{abstract}

\section{1. 日本列島及び周辺の地震の特徵}

日本列島全体の地震活動は、プレートテクトニクス 説で説明することができます。日本列島周辺のプレー トは、海のプレートとして太平洋プレート、フィリピ ン海プレート、陸のプレートとしてはユーラシアプレ 一ト、北米プレートがあり、4 つのプレートの相互作 用によって日本列島の地震活動、火山活動などが説明 される。西日本（西南日本）では、ユーラシアプレー ト（日本列島）の下へ海のプレート（フィリピン海プ レート、太平洋プレート）が潜り込んでいます。日本 列島を 2 つ地域に分け、東北日本弧、西南日本弧と

\section{内陸で起きる地震}

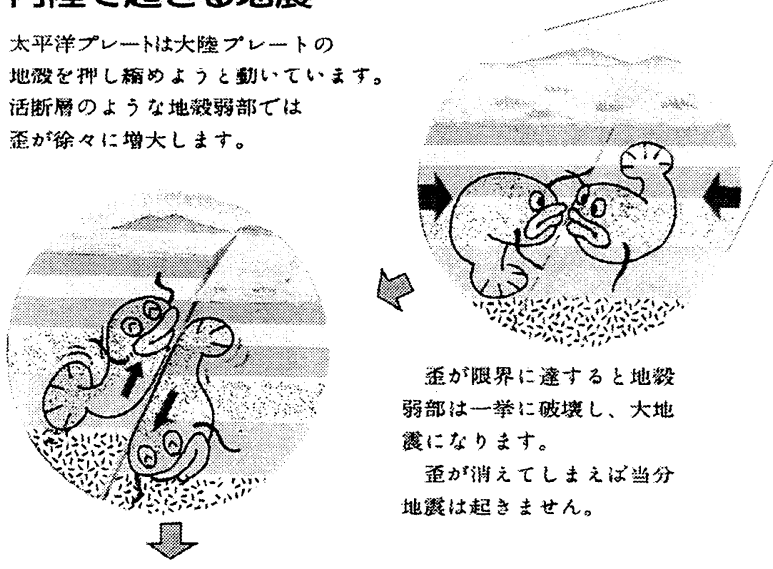

図 1 日本列島で起きる被害地震の 2 つの型

\section{海底で起きる巨大地震}

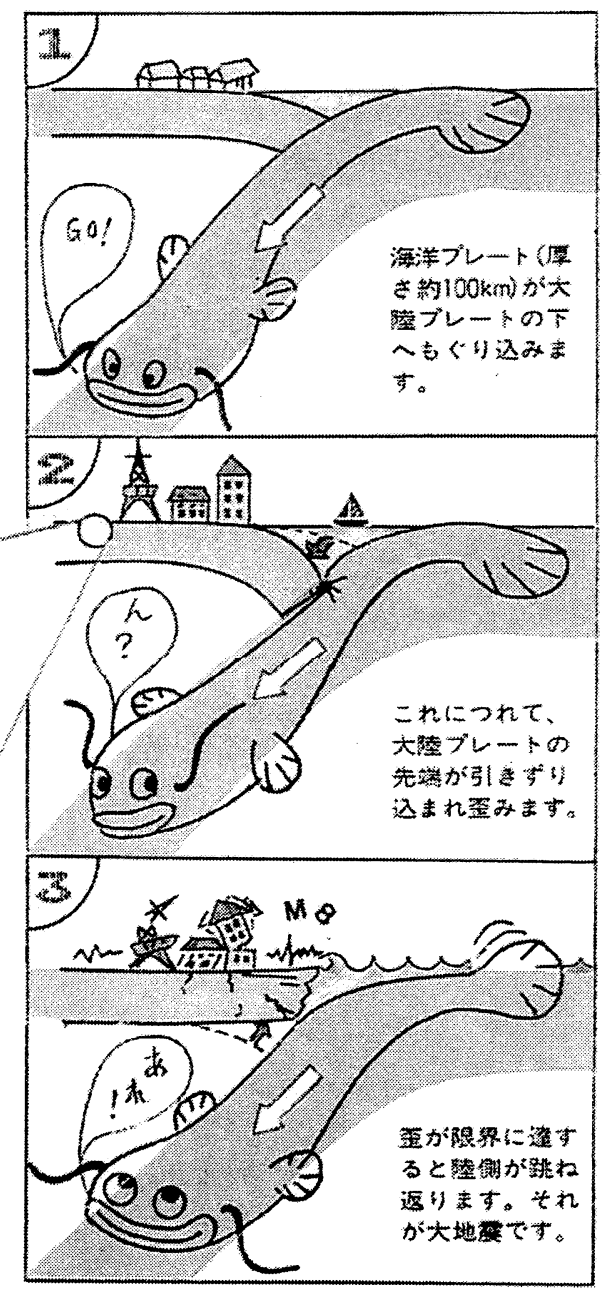


してその特徴を見る。東北日本弧はサブダクションゾ ーンと言われる典型的な特徽を備えている。海洋底一

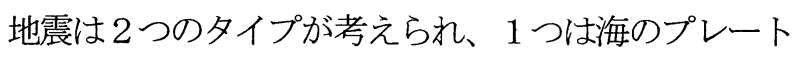
が陸のプレートの下に潜り込むことによる海溝（ある いはトラフ)に発生するプレート境界の巨大地震です。 広範囲の地震動被害と津波災害が発生するマグニチュ ード8クラスの巨大地震で、南海地震 (1946 年、M8. 1)、 東南海地震 (1944 年、M7.9) です。他のタイプは内陸地 震といわれ、マグニチュード7クラスで都市の近傍で 発生すると大きな被害を出す地震です。鳥取地震 (1943 年、M7.2)、兵庫県南部地震 (1997 年、M7.2)、そして 鳥取県西部地震などである。プレートの移動によって、 地球内部に歪エネルギーが蓄積され、限界に達すると 地震を発生させて解消する。その時、震源では地下断 層がずれ、震源断層の形成される。これは地域に作用 している地殼応力と地下の断層系に関連している。陸 地域の地殼上部に発生する時は地表面の活断層と関連 し、地震断層が地表面に現れる。

\section{2. 大地震による被害の特徴}

日本列島周辺で発生する被害地震、(1)プレート境界 の巨大地震 : 海溝と列島の間の海底、海のプレートが 陸のプレートの下に潜り込むことにより発生。(2)内陸 地震、陸のプレートが圧縮力を受け地殼上部で発生す る地震について、海のプレートが陸のプレートの下に 潜り込んで行く運動により、2つの地震のメカニズム が説明され、被害の特徵も大きく異なる。明治以後で、 大災害を引き起こした大地震についてその特徴を示す。

(1)濃尾大震災（濃尾地震；1891 年 10 月 28 日 6 時 38 分、 $M=8.0$ 、岐阜県西部根尾谷） 分類(2) 内陸で発生した最大の地震、地震断層（根尾谷断 層(長さ $31 \mathrm{~km}$ 、最大ずれ $8 \mathrm{~m}$ )など) が地表面に現れ た。地表面の地震動汃強く、死者 7,273 人、全壊 家屋 14 万戸以上、山崩れ、道路・橋梁崩壊、堤防 損壊など、直接的な原因による被害が多く発生し た。

（2） 1896 年三陸地震津波（三陸地震；1896 年 6 月 15 日 19 時 32 分、 $M=8.5$ 、岩手県沖) 分類(1) 日本海溝下の太平洋プレート境界の逆断層型の巨 大地震。地震動はゆるく、震害はなかった。地震 後 30 分〜1 時間に東北地方の太平洋沿岸に最大 $30 \mathrm{~m}$ に及ぶ津波が襲来し、流出家屋 8000 戸以上. 溺死者約 22,000 人、満潮時と重なったために被害 が大きくなった。約 40 年後にほとんど同じ場所に 三陸地震 (1933 年 3 月 3 日 2 時 30 分、 $M=8.1$ 、岩 手県沖) が発生して、死者・行方不明 3,000 人以上、 流出家屋 4000 戸以上の同様の大被害を出した。

(3) 関東大震災 (関東地震; 1923 年 9 月 1 日 11 時 58 分、 $M=7.9$ 、相模湾海底下)

分類(1)
相模湾下のプレート境界のずれで地震が発生した。 伊豆半島、三浦半島、房総半島で地壳変動が観測 され、津波も発生した。被害は関東地方全域で、 死者 14 万人以上、地震動による全壊家屋は 12 万 8 千余、半壊は 12 万 6 千余、二次災害である火災 による焼失家屋は、44 万 7 千余、死者の内 10 万 人以上が焼死者であった。

(4) 南海地震災害 (南海地震 : 1945 年 12 月 21 日 4 時 19 分、 $M=8.0$ 、紀伊半島沖） 分類(1)

南海トラフ沿いの逆断層型の巨大地震、フィリピ ン海プレートの沈み込みによる逆断層型地震。被 害は地震動によるものは、家屋の全壊 1 万 1 千戸 以上、半壊 2 万 3 千戸以上で、西日本一帯に及ん でいる。津波による流出家屋は約 1500 戸に及んで いる。室戸岬の地震前の隆起、地震による沈降は プレート境界地震の地款変動のモデルを確立した。

(5) 阪神淡路大震災 (兵庫県南部地震 ; 1995 年 1 月 17 日 05 時 45 分 $M=7.2$ 明石海峡付近） 分類(2) 都市直下に発生した内陸地震。地表面に地震断層 として野島断層が出現し、震源断層は約 $50 \mathrm{k} \mathrm{m}$ の 右横ずれ断層で、神戸市・阪神地域に震度 7 の震 災の帯が出現した。6000 人以上の人が亡くなり、 数万戸の全半壊家屋を出した。高速道路のコンク リート橋脚など鉄筋鉄骨の建造物が崩壊し、都市 災害の恐ろしさを再認識させた。

\section{3. 鳥取県西部地震の特徴}

鳥取県西部は米子市、境港市を中心に、中海・弓r 浜・三保湾の海岸地域を中心に発展している。一方、 山間地もたたら鉣業に代表される古くからの鉄鋼の産 地であった。11 年前、平成元年 10 月 27 日にM5. 3 の 地震が日野町の地下で発生し、以後 M5 クラスの中地震 が群発した。これぶ 2000 年鳥取県画部地震の始まりで ある。

平成 12 年 10 月 6 日午後 1 時 30 分に「平成 12 年鳥 取県西部地震」(M7.3) は、震度 6 強を日野町、境港市 で記録し、山間部に発生した地震でありながら大きな 被害を出している。しかし、幸いにも亡くなった人が なかったが、重傷 20 人、軽傷 77 人、全壊家屋が 338 戸、半壊 1939 戸と、斜面崩壊・落石などによる道路・ 鉄道の不通箇所を多く出している。また、ライフライ ンの被害も 15,000 件にも達している。沿岸地域では液 状化現象による港湾の破損は地場産業に大きな打撃を 与えている。兵庫県南部地震による阪神・淡路大震災と は規模がほぼ同じでありながら際立った違いを示して いる。

\section{(1) 震度分布}

地震が発生すると、テレビの画面に最初に震度情報 が出る。震度はその場所の摇れの強さを表すもので、 


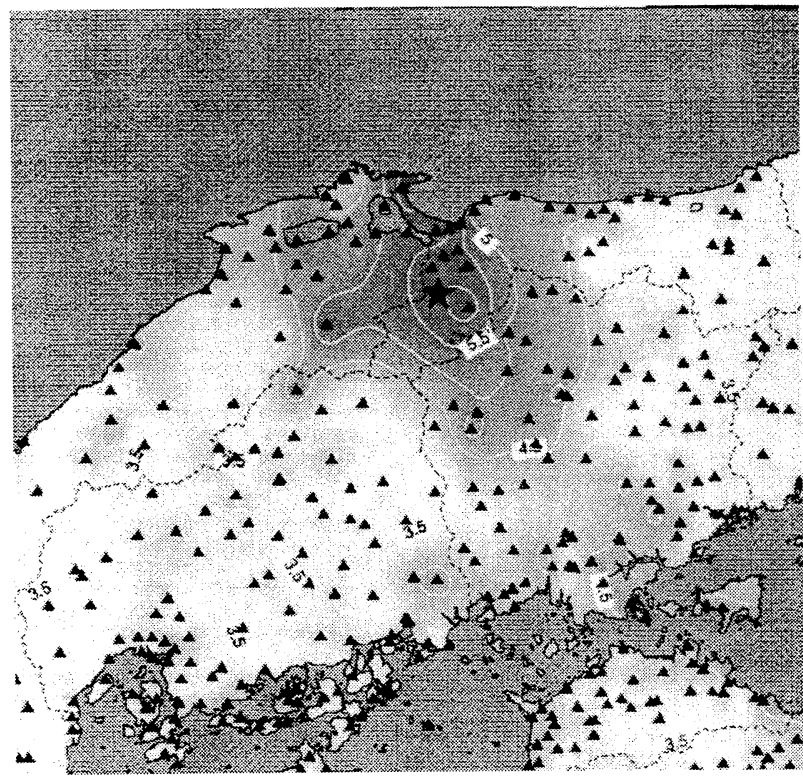

図2 鳥取県西部地震の震度分布

震央に近い所では大きな震度を震度を示し、遠くにな ると小さい值を示す。今回の地震の主な震度を以下に 示す。

震度 6 強 : 日野町、境港市

6 弱 : 西伯町、溝口町

5 強: 米子、新見、岡山哲多、落合、香川土庄 5 弱 : 松江、東郷、岡山、玉野、福山、徳島

4 : 鳥取、出雲、倉敷、広島、高松、松山、 高知、大阪、神戸

詳しい震度分布でも見えるが、上の震度の表でも、

今回の地震の特徵が見えてくる。

(1) 山間部の日野町と沿岸部の境港が「震度 6 強」

(2) 震度の大きな地域が岡山県から四国まで、南側に広 がっている。

(3) 松江、鳥取、出雲など、震源までの距離が近いのに 震度が小さい。

(2) 本震と余震分布

本震の震源は西伯町の地下 $10 \mathrm{~km}$ の所で、マグニ チュード 7.3 と日本海沿岸の地震では最大級の地震 です。地震の解析から、震源断層は北北西一南南東の 走行で、約 $20 \mathrm{~km}$ の長さで幅約 $10 \mathrm{~km}$ の左横ずれ断層を 示し、地震を起こした地殼応力は東西方向から約 30 度時計回りに回った方向です。

余震活動は、特異な分布を示している。多くの余震 は震源断層に沿った細長い帯状の地域に集中している、 本震の震源より南側（西伯町から日野町）では線状配 列を示しているが、北側（西伯町から島根県伯太町・ 安来市) では余震分布が複雑で、時間経過とともに余 震が多発している。最大余震M 5.0 も北の端近くに発 生している。しかし、余震活動は通常の経過で減衰し ている。そして、誘発地震群が 2 ケ所あり、割算型の

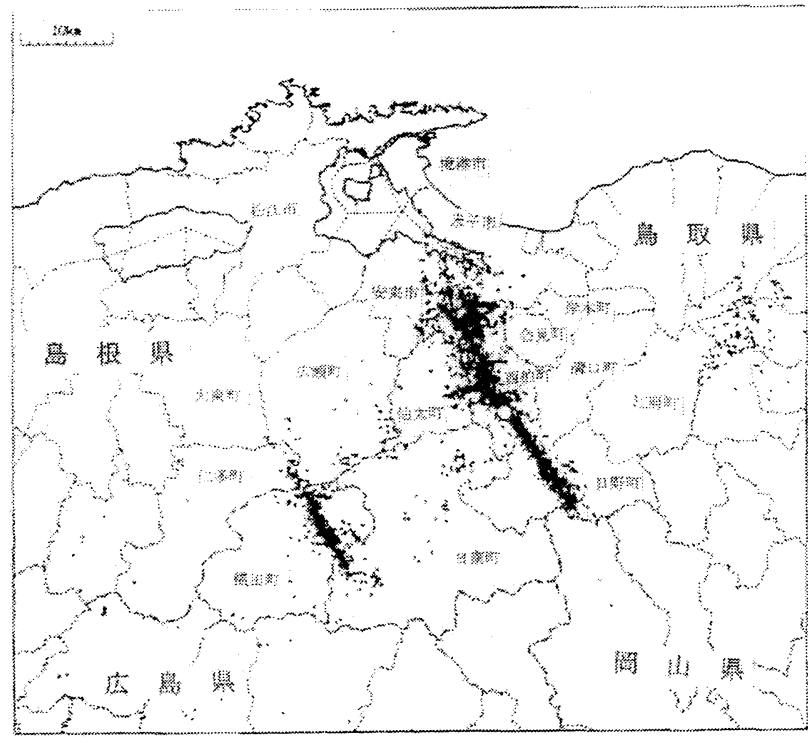

図 3 鳥取県西部地震の余震と誘発地震群の分布

分布をしている。南西に約 $10 \mathrm{~km}$ 離れた日南一横田町で はマグニチュード5.5.の地震が発生し、その後この地 域全体に地震が発生している。北東に約 $15 \mathrm{~km}$ 離れた大 山付近の活動は鳥取県中部まで、東西 $50 \mathrm{~km}$ 以上の地域 で地震活動が活発になっている。

\section{4. 鳥取県西部地震までの地震活動}

\section{一鳥取県中部・西部、島根県東部一}

880 年出雲地震 (M7. 0) 以来、大地震は発生していな い。しかし、最近の 20 数年間の地震活動は主にこの地 域に集中している。今回の地震の西の地域では 1977 年 (M5. 3)、1978 年(M6. 1) と三瓶山周辺で発生し、小 地域ながら被害を出し、温泉の増水、泉温の上昇など 異変を発生させた。この地域の活動は最近でも継続さ れている。広島県北部も群発地震が発生する地震活動 域である。

東の地域では、鳥取県中部の地震(1983 年、M6.2)、 1985 年には大山付近の地震 (M4.9) が大山山頂から数 $\mathrm{km}$ 東に発生した。そして、今回の 2000 年鳥取県西部 地震を含む鳥取一島根県境地域の活動では、1989、1990、 1997 年と群発地震が継続した。1991 年数 $\mathrm{k} \mathrm{m}$ 西に島根 県東部の地震（M5.9）が発生した。これら一連の活動 は、約 20 年間の地震活動が東から西へと移動し、地震 が集中して行くことが見られた。また、これらの中地 震の地震を起こした地下断層は発震機構からいずれも 左横ずれ断層で、地殼応力は大体東西方向または時計 回りに少し回転した圧縮力を示している。今回の地震 の震源断層、地款応力はこれらとほぼ一致している。

鳥取県西部地域では 1901 年、1925 年、1955 年にM 5 クラスの地震活動があり、約 30 年間隔で活発化して いる。震源断層の地震活動は、鎌倉山南方活断層に直 交する地下断層系の活動で、1989 年に M5. 3、M5. 4 は 


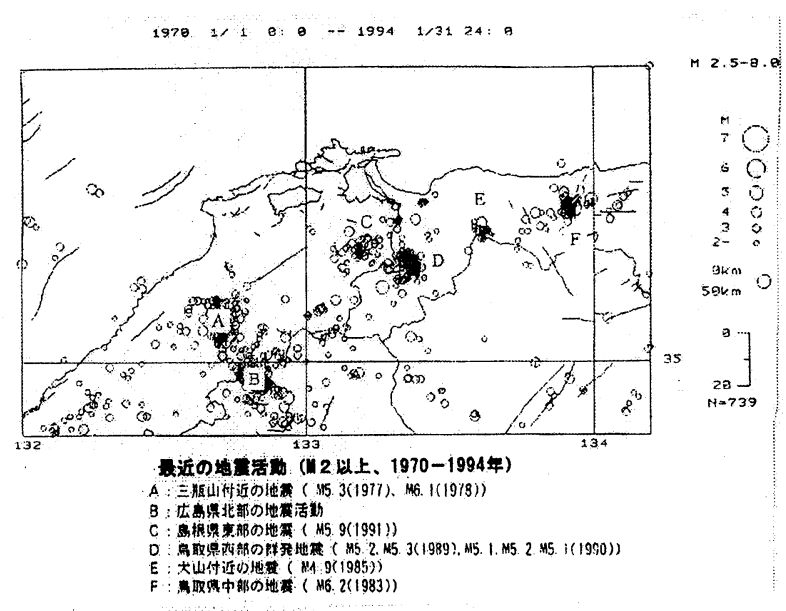

図4 島根半島周辺の最近の地震活動

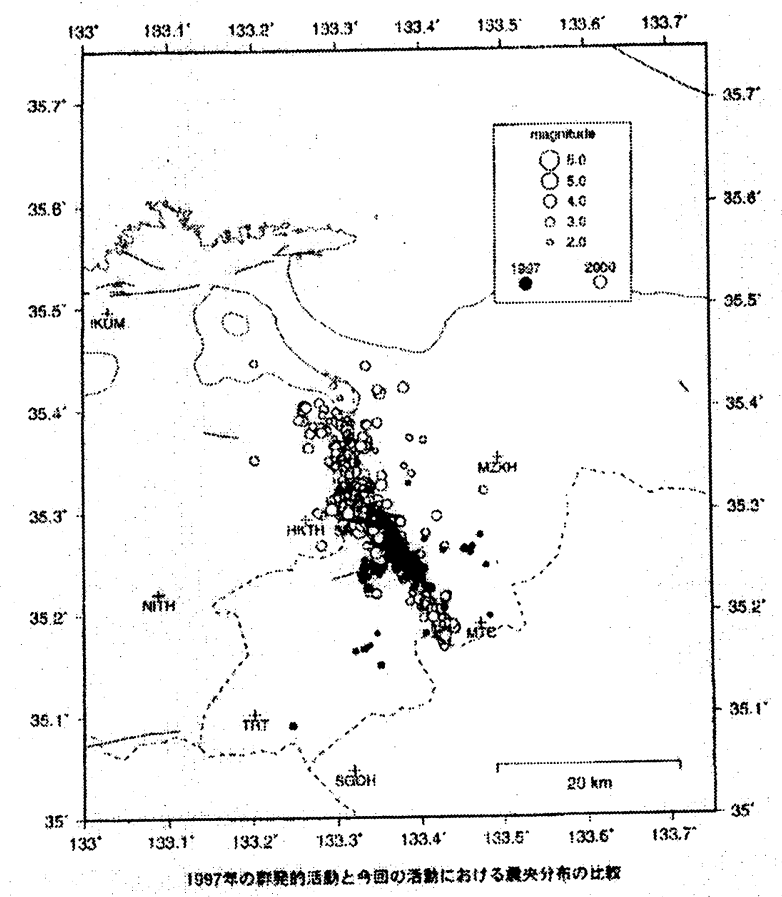

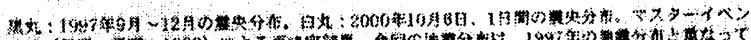

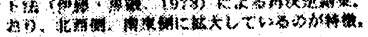

図 5 鳥取県西部地震の震源断層の前駆的地震活動

断層の南側 (主に日野町) で地震があり, 1990 年に M5. 1， M5. 2，M5. 1，1991 年には M4. 6 は断層の北側（主に西 伯町）で地震が活発になり、1997 年に M5. 2 は今まで の活動域全域で地震か発生し、11 年前から群発地震を 繰り返して、震源断層が形成されている。

5. 最近の西日本の地震活動一兵庫県南部地震、 鳥取県西部地震、兵庫県北部地震、芸予地震一 地震活動はプレート運動が続く限り地下に歪が蓄積 され、歪を解消するために地震が発生する。しかし、 地震活動は時間的に消長を繰り返している。ここ 10 年間の地震活動は西日本に大地震の発生が集中してい る傾向が見える。1995 年の兵庫県南部地震は 1948 年 福井地震から約 50 年ぶりの内陸大地震であった。そし
て、2000 年 10 月 6 日の鳥取県西部地震 (M7.2) が山 陰地方で発生した。その後、1月 10 日兵庫県北部地震 (M5. 4)、3 月 24 日に芸予地震 (M6.2) と地震が続発 した。これらの地震活動の集中の意味をプレートテク トニクス説で考察する。

西南日本内帯と言われる地域はユーラシアプレート とフィリピン海プレート、太平洋プレートの相互作用 で説明される。近畿地方には活断層が発達し、地震活 動もこの地域で議論されている。地殼上部に発生する 内陸地震は太平洋プレートの影響を受けて、東西圧縮 力で地震が発生し、横ずれ断層が卓越する。これによ る地震が最近の一連の活動である。しかし、西日本の 最大の地震は南海トラフに発生する南海地震である。 この地域の地震活動は歴史的に解明されていて、その 繰返し周期が判明している。

1946 年南海地震 (M8.0) の前後の地震活動では、地 震前後に明瞭な地震活動の差が見られる。南海地震前、 40 年間に内陸地震が多発する地震活動期があり、地震 後 40 年間は地震活動の静穏期であった。1995 年兵庫 県南部地震以後、地震活動が活発化し、次の南海地震 へのステージに入ったことが、地震学者の中で認識さ れてきている。これから、南海地震が発生するまでに 何回かの内陸地震を経験することが想定される。そし て、これは1地方に限られたことではなく、それぞれ の地域での防災対策を実施することが急がれる。

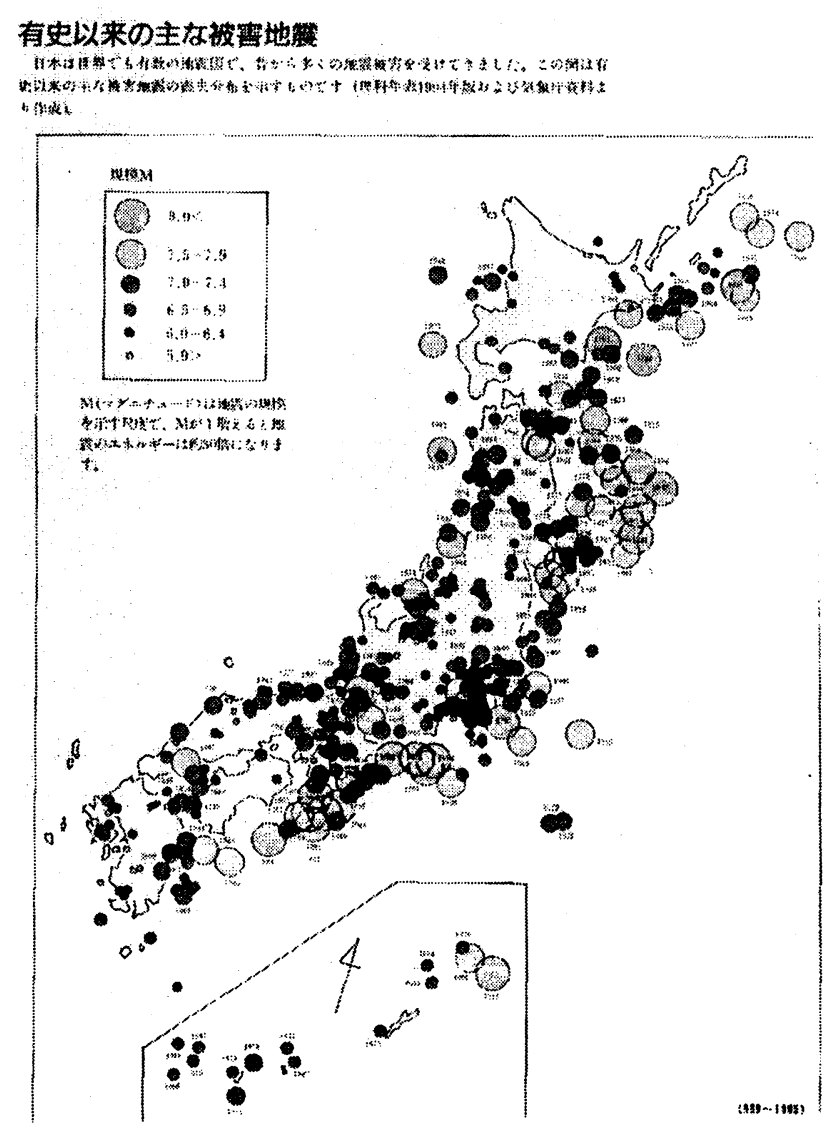

図6 日本列島の被害地震分布 